\title{
Alat Pemberi Pakan Ikan Otomatis Berbasis Suhu Air Pada Kolam Ikan
}

\author{
Sandya Pratisca ${ }^{1}$, Juli Sardi ${ }^{2}$ \\ ${ }^{1}$ Universitas Negeri Padang \\ Jl. Prof Dr. Hamka Air Tawar, Padang \\ sandyapratisca@gmail.com,JuliSardi@ft.unp.ac.id
}

\begin{abstract}
Feeding fish is closely related to the rate of growth and devolepment of fish. The problems faced by farmers are the cost of producing fish feed which is sometimes expensive and the strategy of feeding fish that is not effective and efficient. Therefore, this study aims to design an automatic fish feeder based on water temperature in a fish pond using Arduino, this research made a prototype consisting of Arduino IDE software for coding systems and hardware equipped with Arduino 2560. HC-SR04 ultrasonic sensor, DS18S20 temperature sensor, loadcell sensor, real time clock (RTC), servo motor, DC motor, buzzer, and LCD. After several experiments, all components in this system are able to work in accordance with the research objectives. This tool can be an alternative that can be applied by farmers in feeding fish efficiently.
\end{abstract}

Keywords - automatic fish feeder, arduino mega 2560, DS18S20 temperature sensor, RTC.

\begin{abstract}
Abstrak-Pemberian pakan ikan sangat erat kaitannya dengan laju pertumbuhan dan perkembangan ikan. Permasalahan yang dihadapi peternak adalah biaya produksi pakan ikan yang terkadang mahal dan strategi pemberian pakan yang tidak efektif dan efisien karena takaran pakan yang diberikan tidak sesuai dengan suhu air pada kolam yang berpengaruh terhadap nafsu makan ikan. Penelitian ini bertujuan untuk membuat alat pemberi pakan ikan otomatis berbasis suhu air pada kolam ikan. Penelitian ini membuat alat mencakup hardware dan software. Hardware meliputi arduino 2560, sensor ultrasonik HC-SR04, sensor suhu DS18S20, sensor loadcell, real time clock (RTC), motor servo, motor DC, buzzer, LCD dan software arduino IDE untuk pengkodean sistem. Setelah dilakukan beberapa percobaan, semua komponen dalam sistem ini mampu bekerja sesuai dengan tujuan penelitian. Alat ini bisa menjadi alternatif yang bisa diterapkan oleh peternak dalam pemberian pakan ikan secara efisien.
\end{abstract}

Kata kunci- pakan ikan otomatis,arduino mega 2560, sensor suhu DS18S20, RTC.

\section{Pendahuluan}

Perikanan di Indonesia merupakan salah satu penunjang pemasukan negara yang cukup signifikan. Salah satu faktor pendukung meningkatnya produksi ikan adalah ketersediaan pakan[1]. Biaya produksi pakan yang terkadang terlalu mahal dapat menjadi kendala dalam budidaya ikan. Untuk mengurangi biaya tersebut sebaiknya penggunaan pakan dilakukan secara efisien [2]. Namun kondisi yang dihadapi dilapangan, sistem pemberian pakan masih dilakukan secara manual. Sehingga takaran pemberian pakan tidak menentu dan juga menyebabkan lamanya pemberian pakan pada ikan jika peternak memiliki kolam yang banyak [3]. Menabur pakan dengan rata dan tersebar diseluruh kolam merupakan metode pemberian pakan terbaik yang bisa dilakukan dalam mengatasi hal ini. Adapun salah satu faktor penting yang mempengaruhi pertumbuhan dan kelangsungan hidup ikan adalah suhu. Karena suhu dapat mempengaruhi pertumbuhan dan nafsu makan ikan [4].

Sebelumnya sudah banyak dibuat pembaruan untuk mengatasi permasalahan tersebut yang memaparkan tentang perancangan sebuah alat yang dapat memberi makan ikan secara otomatis dan mendeteksi suhu ketika berada dalam dalam keadaan tidak normal. Pengendalian utama pada alat ini menggunakan mikrokontroler ATMega 8535 aktivitas-aktivitas yang telah dilakukan akan diinformasikan melalui SMS menggunakan GSM ke satu nomor telepon tertentu [5]. Selain itu juga terdapat penelitian tentang sebuah alat yang dapat menampilkan suhu yang terukur dari sensor DS18B20, pemantauan kejernihan air dari sensor LDR serta pemberian pakan ikan berdasarkan waktu yang telah disetting pada RTC (Real Time Clock)[6].

Berdasarkan penelitian yang sudah direview penulis berinovasi membuat alat dimana jumlah pakan yang diberikan berdasarkan suhu air pada kolam ikan. Sehingga jumlah pakan yang diberikan sesuai dengan kebutuhan dan nafsu makan ikan. Pada perancangan ini mikrokontroler arduino sebagai pengendali utama, motor servo untuk membuka dan menutup katup plat, motor dc sebagai penggerak sistem yang bekerja berdasarkan data yang terdapat pada RTC (Real Time Clock), sensor ultrasonik sebagai pendeteksi ketersediaan pakan, sensor DS18S20 untuk mengukur suhu air pada kolam, sensor loadcell sebgai penghitung berat pada pakan dan LCD yang menampilkan waktu, tanggal, kondisi pakan serta suhu air. 


\section{METODE}

Metode yang digunakan dalam penelitian ini adalah membuat alat pemberi pakan ikan otomatis berbasis suhu pada kolam ikan serta pelaksanaan percobaan pengujian pada masing-masing komponen.

\section{A. Blok Diagram}

Secara keseluruhan alat pemberi pakan ikan otomatis berbasis suhu air pada kolam ikan menggunakan arduino terdiri dari beberapa bagian, yaitu: input berupa sensor ultrasonic HC-SR04, sensor loadcell, sensor suhu DS18S20, RTC, serta output berupa driver motor dc, motor dc, motor servo, LCD dan buzzer. Berikut blok diagram keseluruhan seperti dibawah ini.

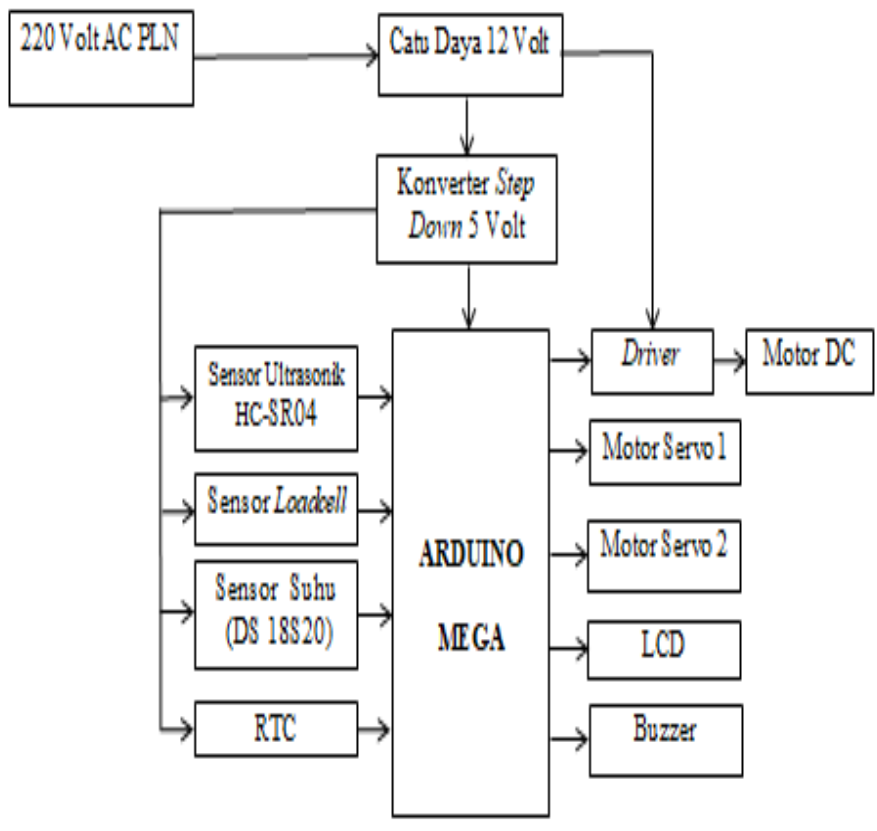

Gambar 1. Blok Diagram Keseluruhan

Berdasarkan blok digram keseluruhan sistem diatas, fungsi dari masin-masing blok diagram sebagai berikut:

1. Catu Daya merupakan supply tegangan seluruh sistem.

Pada diagram blok ini menggunakan catu daya $12 \mathrm{~V}_{\mathrm{dc}}$ yang berfungsi sebagai supply tegangan untuk motor DC.

2. Konverter Stepdown merupakan modul yang berfungsi mengkonversikan atau menurunkan tegangan dari catu daya $12 \mathrm{~V}_{\mathrm{dc}}$ menjadi $5 \mathrm{~V}_{\mathrm{dc}}$ sebagai supply tegangan untuk arduino beserta input pada alat.

3. Arduino Mega merupakan mikrokontroler dengan chip Atmega 2560 pada alat ini berfungsi sebagai pusat pemrosesan kendali sesuai dengan input yang diberikan.

4. Sensor Ultrasonik HC-SR04 berfungsi mengukur ketinggian pakan (pelet) pada tangki pakan.

5. Sensor Loadcell berfungsi untuk menimbang banyaknya pakan (pelet) yang akan dikeluarkan dari tangki pakan.
6. RTC(Real Time Clock) berfungsi sebagai blok untuk menyimpan data waktu pemberian pakan.

7. Motor Servo pada tugas akhir ini menggunakan 2 buah motor servo, motor servo 1 digunakan untuk membuka dan menutup katup plat pada tangki pakan dan motor servo 2 digunakan untuk menggerakkan tempat pakan setelah ditimbang menuju wadah penampung.

8. Motor DC berfungsi sebagai penggerak sistem.

9. LCD berfungsi untuk menampilkan waktu (jam, menit, detik), tanggal, kondisi pakan, waktu pemberian pakan dan suhu air.

\section{B. Flowchart}

Prinsip kerja alat ini dijelaskan melalui suatu gambar atau bagan yang menunjukkan langkah atau urutan suatu program. Flowchart untuk sistem otomatisasi pakan ikan berbasis suhu air ditunjukkan pada gambar 2 .

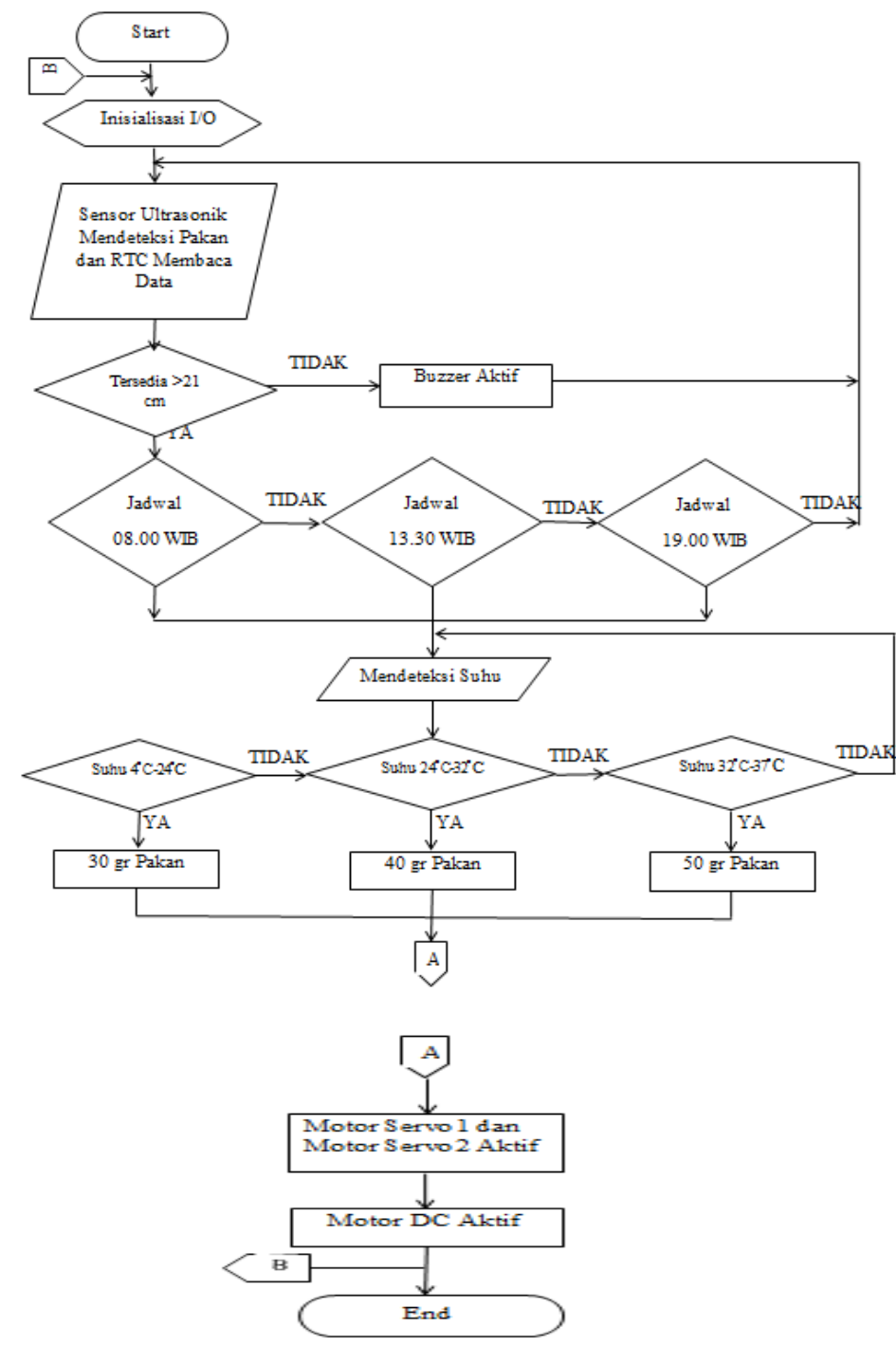

Gambar 2. Flowchart

Pada gambar 2 diatas merupakan flowchart atau diagram alir cara kerja alat secara keseluruhan. Sistem diawali dengan inisialisai input dan output. Sensor 
ultrasonik mendeteksi jarak pakan dengan sensor dan RTC membaca data. Jika waktu yang ditunjukkan oleh RTC sama dengan waktu yang telah disetting maka sensor suhu akan mengukur kondisi air pada kolam, suhu dibagi atas tiga kategori sehingga jumlah pakan berbeda- disesuaikan dengan kategori suhu yang terbaca oleh sensor. Selanjutnya sensor loadcell akan menimbang jumlah pakan sesuai dengan suhu air yang terbaca oleh sensor suhu. Setelah pakan sesuai dengan settingan yang disesuaikan dengan suhu air, motor servo 1 aktif membuka katup plat pada tangki sehingga pakan turun menuju wadah penampung dan motor servo 2 aktif menumpah pakan diwadah penampung menuju pelontar. Selanjutnya motor DC aktif dan melontar pakan pada kolam ikan.

\section{Perancangan Hardware}

Perancangan hardware merupakan suatu tahapan atau proses dalam pembuatan suatu perangkat keras. Perancangan hardware bertujuan untuk memudahkan serta mengurangi tingkat kesalahan dalam membuat perangkat keras sehingga mendapatkan hasil yang optimal. Rancangan alat seperti gambar 3.

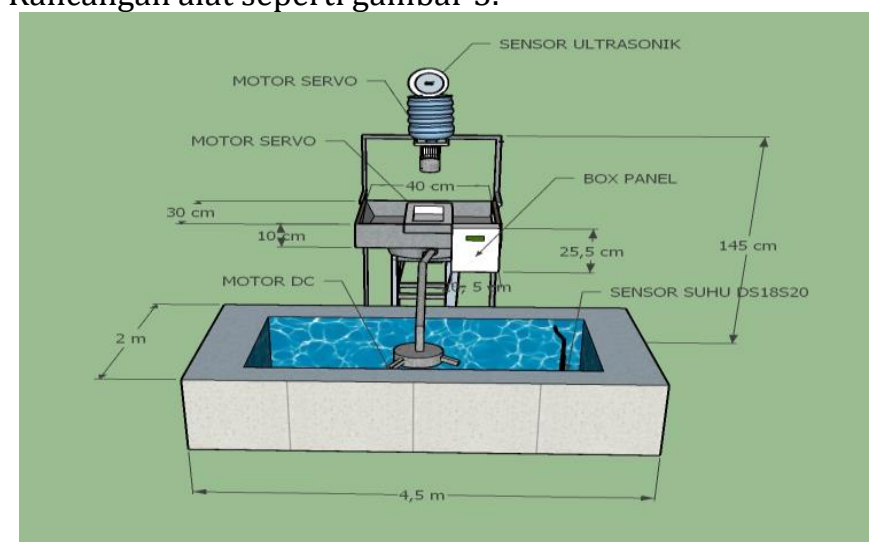

\section{Perancangan Software}

Perancanagan software secara keseluruhan pada tugas akhir ini menggunakan Arduino IDE (Integrated Development Environment), yaitu software yang merupakan bawaan dari arduino itu sendiri, sehingga dapat mengendalikan seluruh input dan output yang digunakan pada sistem otomatisai pemberian pakan ikan. Pada software Arduino IDE dapat dilakukan proses compile dan upload program yang dibuat ke dalam mikrokontroler arduino. Kode-kode program arduino dibuat menggunakan bahasa pemograman C. Untuk komunikasi antara perangkat dengan pengguna, penulis akan memberikan input untuk mengatur kontrol otomatis pada pemberian pakan ikan, serta hasil dari pengaturan akan tampil melalui LCD.

\section{HASIL DAN PEMBAHASAN}

Pada bagian ini dilakukan pengujian dan pembahasan untuk seluruh bagian input dan output. Pengujian dan pembahasan dilakukan untuk mengetahui sistem otomatisasi pemberian pakan ikan dapat berfungsi dengan baik atau tidak sesuai dengan rancangan. Pengujian sistem otomatisasi pemberian pakan ikan meliputi pengujian sensor suhu DS18S20 yang berfungsi untuk memantau keadaan suhu air, dimana hasil dari pembacaan sensor suhu akan menjadi acuan jumlah pakan yang akan diberikan pada ikan, pengujian sensor ultrasonic HC-SR04 yang berfungsi untuk mengukur banyak pakan pada tangki pakan, pengujian sensor loadcell yang berfungsi untuk menimbang berat pakan yang akan dikeluarkan, RTC yang berfungsi sebagai modul pewaktu untuk waktu pemberian pakan ikan, pengujian motor servo 1 berfungsi untuk mengetahui derajat ideal bukaan katup plat pada tangki pakan, pengujian motor servo 2 berfungsi untuk mengetahui derajat ideal motor memutar tempat pakan setelah ditimbang menuju wadah penampung dan pengujian motor dc berfungsi untuk mengetahui seberapa jauh pakan terlontar, dimana setiap langkah input dapat dilihat melalui LCD. Gambar berikut ini merupakan tampilan alat secara keseluruhan.

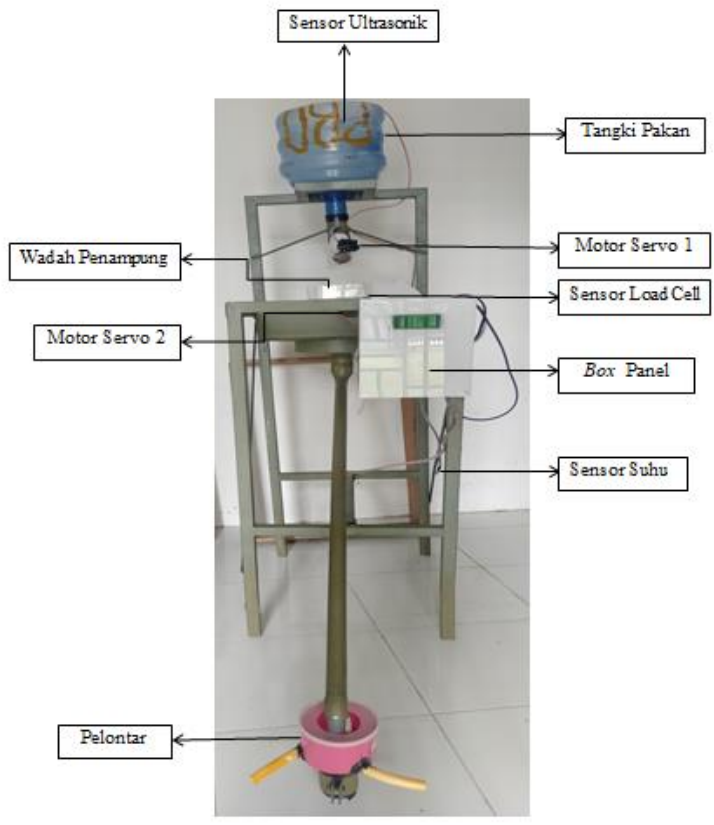

Gambar 4. Tampilan Alat Secara Keseluruhan

\section{A. Pengujian Hardware}

1. Pengujian Rangkaian Sensor Ultrasonik

Penggunaan sensor ultrasonic berfungsi untuk mengetahui banyak pelet didalam tangki pakan dengan mengukur jarak pelet dengan sensor. Untuk melakukan pengujiannya sensor diletakkan pada bagian tutup tangki pakan, sehingga pantulan dari senor menjadi acuan dalam membaca jarak. Pengujian rangkaian ultrasonic dilakukan dengan suatu perbandingan antara sensor ultrasonic dengan penggaris [7]. Pengujian sensor bertujuan untuk 
mengetahui tingkat akurasi pembacaan sensor dan eror dari data hasil pengukuran jarak pada sensor ultrasonik.

Ragam ralat dari pengukuran dibagi menjadi 3 bagian yaitu ralat sistematis (systematic eror), ralat rambang (random error) dan ralat kekeliruan [8].

Dari perbandingan antara sensor ultrasonic dengan penggaris dapat dijabarkan untuk mencari eror dan menghitung \%eror yaitu:

Error $=\mid$ jarak sebenarnya - jarak terukur $\mid$

$\%$ Error $=\frac{(\text { Jarak Sebenarnya }- \text { Jarak Terukur })}{\text { Jarak Sebenarnya }} \times 100 \%$

Perbandingan pengujian sensor ultrasonic dan penggaris dapat dilihat pada table 1 .

Tabel 1. Data Hasil Pengujian Sensor Ultrasonik

\begin{tabular}{|c|c|c|c|c|}
\hline No. & $\begin{array}{c}\text { Menggunakan } \\
\text { Penggaris } \\
(\mathrm{cm})\end{array}$ & $\begin{array}{c}\text { Pengujian dengan } \\
\text { Sensor HC-SR04 } \\
(\mathrm{cm})\end{array}$ & $\begin{array}{c}\text { Selisih } \\
\text { Eror }\end{array}$ & $\begin{array}{c}\% \\
\text { Eror }\end{array}$ \\
\hline 1. & 11 & 11 & 0 & 0 \\
\hline 2. & 12,74 & 12,54 & 0,20 & 1,56 \\
\hline 3. & 14,80 & 14,61 & 0,19 & 1,28 \\
\hline 4. & 17,90 & 17,54 & 0,36 & 2,01 \\
\hline 5. & 19,50 & 19,28 & 0,22 & 1,12 \\
\hline \multicolumn{5}{|c|}{ Rata-rata eror } \\
\hline
\end{tabular}

Berdasarkan pengujian yang telah dilakukan terlihat bahwa sensor ultrasonic HC-SR04 dapat bekerja dengan baik sebagai pengukuran ketinggian pelet pada tangki pakan. Hal ini dapat dilihat dari akurasi pembacaan sensor HC-SR04 dapat bekerja dengan baik sebagai pengukuran ketinggian pelet pada tangki pakan. Hal ini dapat dilihat dari akurasi pembacaan sensor HC-SR04 sebesar 98,81\%.
2. Pengujian Rangkaian Real Time Clock (RTC 3231)

Modul RTC 3231 berfungsi sebagai blok untuk menyimpan data waktu pemberian pakan. Pengujian Real Time Clock (RTC) terdapat pada tabel 2.

Table 2. Pengujian Real Time Clock (RTC)

\begin{tabular}{|c|c|c|c|}
\hline No. & Keterangan & Waktu RTC & $\begin{array}{c}\text { Waktu yang } \\
\text { sebenarnya }\end{array}$ \\
\hline 1 & Percobaan 1 & 07.00 .00 & $07: 00: 00$ \\
\hline 2 & Percobaan 2 & 08.58 .20 & $08: 58: 20$ \\
\hline 3 & Percobaan 3 & 10.40 .05 & $10: 40: 05$ \\
\hline 4 & Percobaan 4 & 12.20 .12 & $12: 20: 12$ \\
\hline 5 & Percobaan 5 & 13.30 .00 & $13: 30: 00$ \\
\hline 6 & Percobaan 6 & 14.35 .25 & $14: 35: 25$ \\
\hline 7 & Percobaan 7 & 16.00 .00 & $16: 00: 00$ \\
\hline 8 & Percobaan 8 & 17.54 .5 & $17: 54: 5$ \\
\hline 9 & Percobaan 9 & 19.00 .00 & $19: 00: 00$ \\
\hline
\end{tabular}

Berdasarkan tabel 2 diatas perbandingan waktu RTC dengan waktu yang sebenarnya dapat dilihat bahwa tidak ada perbedaan antara kedua perbandingan tersebut sehingga dapat dikatakan bahwa RTC yang digunakan dapat bekerja dengan baik.

\section{Pengujian Sensor Loadcell}

Pengujian loadcell dilakukan untuk mengetahui selisih nilai sensor dengan nilai timbangan konvensional. Pengujian sensor ini dilakukan dengan tujuan untuk mengtahui tingkat akurasi pembacaan sensor [9]. Pengujian dilakukan dengan cara pakan yang terdapat dalam tangki di trigger oleh sensor ultrasonik sehingga motor servo membuka katup plat dan menjatuhkan pakan tepat didalam wadah penampung yang berada diatas sensor loadcell. Setelah itu datanya dibandingkan dengan pengukuran berat pada timbangan.

Untuk menghitung tingkat kesalahan (eror rate) dari hasil pengujian sensor loadcell dengan timbangan dapat dihitung dengan persamaan berikut:

$$
\text { Rata-rata kesalahan }=\frac{s-x}{s} \times 100
$$

Keterangan :

$\mathrm{s}=$ nilai pada sensor loadcell

$\mathrm{x}=$ nilai pada timbangan 
Pengujian sensor loadcell terdapat pada tabel 3.

Tabel 3. Pengujian Sensor Loadcell

\begin{tabular}{|c|c|c|c|c|}
\hline No. & $\begin{array}{c}\text { Berat Pakan } \\
\text { pada Sensor } \\
\text { (gram) }\end{array}$ & $\begin{array}{c}\text { Berat } \\
\text { Pakan } \\
\text { pada } \\
\text { Timbangan } \\
\text { (gram) }\end{array}$ & Eror & $\%$ Eror \\
\hline 1 & 41,20 & 41,18 & 0,07 & 0,17 \\
\hline 2 & 41,25 & 41,15 & 0,10 & 0,24 \\
\hline 3 & 41,46 & 41,20 & 0,26 & 0,62 \\
\hline 4 & 41,20 & 41,10 & 0,10 & 0,24 \\
\hline 5 & 42,80 & 42,50 & 0,30 & 0,68 \\
\hline \multicolumn{4}{|c|}{ Rata-rata eror } & 0,39 \\
\hline
\end{tabular}

Berdasarkan tabel pengujian sensor loadcel diatas dengan 5 kali percobaan tingkat kesalahan (eror rate) didapat nilai rata-rata 99,61\%. Sensor ini dapat bekerja dengan baik karena nilai kesalahan (eror) kecil.

\section{Pengujian Sensor Suhu DS18S20}

Pengujian ini dilakukan untuk mengetahui selisih nilai sensor dengan nilai termometer. Pengujian ini dilakukan dengan cara meletakkan sensor dan thermometer ke dalam air.

Untuk mengetahui tingkat kesalahan (eror rate) dari pengujian sensor suhu DS18S20 dengan termometer dapat dihitung persamaan sebagai berikut :

Error $=\mid$ Suhu Sebenarnya - Suhu Terukur $\mid$

$\%$ Error $=\left|\frac{(\text { Suhu Sebenarnya-Suhu Terukur })}{\text { Suhu Sebenarnya }}\right| \times 100 \%$

Pengujian suhu air menggunakan sensor DS18S20 dan thermometer terdapat pada tabel 4 .

Tabel 4. Pengujian suhu air menggunakan sensor DS18S20 dan thermometer

\begin{tabular}{|c|c|c|c|c|}
\hline No. & $\begin{array}{c}\text { Nilai Pada } \\
\text { Termomete } \\
\text { r } \\
(\mathrm{C})\end{array}$ & $\begin{array}{c}\text { Nilai pada } \\
\text { Sensor Suhu } \\
\text { DS18S20 } \\
\text { (C) }\end{array}$ & Eror & \%Eror \\
\hline 1 & 24,30 & 24,30 & 0 & 0 \\
\hline 2 & 26,45 & 26,45 & 0 & 0 \\
\hline 3 & 27,62 & 27,15 & 0,48 & 1,73 \\
\hline 4 & 28,94 & 28,54 & 0,4 & 1,38 \\
\hline 5 & 30,67 & 30,27 & 0,4 & 1,30 \\
\hline 6 & 33,05 & 32,25 & 0,8 & 2,42 \\
\hline \multicolumn{4}{|c|}{ Rata-rata error } & 1,13 \\
\hline
\end{tabular}

Berdasarkan tabel pengujian yang telah dilakukan terlihat bahwa sensor suhu DS18S20 dapat bekerja dengan baik. Hal ini dapat dilihat dari akurasi pembacaan sensor suhu DS18S20 sebesar 99,58\%.

\section{Pengujian Motor Servo}

Dalam pengujian motor servo bertujuan untuk mengetahui kemampuan bukaan katub dan penetuan posisi pada motor servo 1 dan motor servo 2 dapat dilihat pada tabel berikut.

Tabel 5. Pengujian Bukaan Katub pada Motor Servo 1

\begin{tabular}{|c|c|c|c|}
\hline \multirow{2}{*}{ No. } & \multirow{2}{*}{$\begin{array}{c}\text { Derajat } \\
\text { Posisi }\end{array}$} & \multicolumn{2}{|c|}{ Status Katup } \\
\cline { 3 - 4 } & Terbuka & Tertutup \\
\hline 1 & 15 & - & $\checkmark$ \\
\hline 2 & 50 & $\checkmark$ & - \\
\hline
\end{tabular}

Pada motor servo 1 disaat bukaan 15, katub plat tertutup sehingga pakan tidak jatuh ke wadah penampung dari tangki pakan dan ketika motor servo 1 mencapai bukaan 50 , katub plat akan terbuka sehingga pakan yang

\begin{tabular}{|c|c|c|c|}
\hline No. & \multirow{2}{*}{$\begin{array}{c}\text { Derajat } \\
\text { Posisi }\end{array}$} & \multicolumn{2}{|c|}{ Status Katup } \\
\cline { 3 - 4 } & 15 & Terbuka & Tertutup \\
\hline 1 & 150 & - & $\checkmark$ \\
\hline 2 & 180 & $\checkmark$ & - \\
\hline
\end{tabular}

terdapat pada tangki jatuh ke waduh penampung.

Tabel 6. Pengujian Bukaan Katub pada Motor Servo 2

Pada motor servo 2 disaat bukaan 15, motor servo tidak membuka katup sehingga wadah penampung diatas sensor loadcell tidak berputar dan pakan tidak menumpahkan pakan dan ketika motor servo 2 mencapai bukaan 180, motor servo 2 akan membuka katup dan pakan tumpah menuju pelontar.

6. Pengujian Motor DC

Pengujian motor DC Bertujuan untuk mengetahui seberapa jauh motor DC melontarkan pakan. Pengaturan jauh lontar pakan dengan mengatur kecepatan dari motor DC [10].

Tabel 7. Pengujian Motor DC

\begin{tabular}{|c|c|}
\hline $\begin{array}{c}\text { PWM (Pulse Width } \\
\text { Modulation }) \\
(\%)\end{array}$ & Jauh Lontaran Pakan \\
\hline 10 & $40 \mathrm{~cm}$ \\
\hline 20 & $1 \mathrm{~m} 30 \mathrm{~cm}$ \\
\hline 30 & $1 \mathrm{~m} 30 \mathrm{~cm}$ \\
\hline 40 & $1 \mathrm{~m} 75 \mathrm{~cm}$ \\
\hline 50 & $2 \mathrm{~m} 56 \mathrm{~cm}$ \\
\hline 60 & $3 \mathrm{~m}$ \\
\hline 70 & $3 \mathrm{~m} 43 \mathrm{~cm}$ \\
\hline 80 & $3 \mathrm{~m} 63 \mathrm{~cm}$ \\
\hline 90 & $3 \mathrm{~m} 90 \mathrm{~cm}$ \\
\hline 100 & $4 \mathrm{~m} 20 \mathrm{~cm}$ \\
\hline
\end{tabular}




\section{B. Pengujian Software}

\author{
1. Program Pembacaan RTC 3231 \\ Berikut list programnya : \\ DateTime MyDateAndTime; \\ MyDateAndTime=Clock.read(); \\ lcd.clear0; \\ lcd.setCursor $(0,0)$; \\ lcd.print("Tanggal : "); \\ lcd.print(MyDateAndTime.Day); \\ lcd.print("/"); \\ lcd.print(MyDateAndTime.Month); \\ lcd.print("/"); \\ Icd.print(MyDateAndTime.Year) \\ lcd.setCursor(0,1); \\ lcd.print("Jam : "); \\ lcd.print(MyDateAndTime.Hour); \\ lcd.print(":"); \\ lcd.print(MyDateAndTime.Minute); \\ lcd.print(":"); \\ lcd.print(MyDateAndTime.Second);
}

Pada kode program MyDateAndTime berfungsi untuk menyimpan data berupa tanggal dan waktu yang menjadi acuan pemberian pakan.

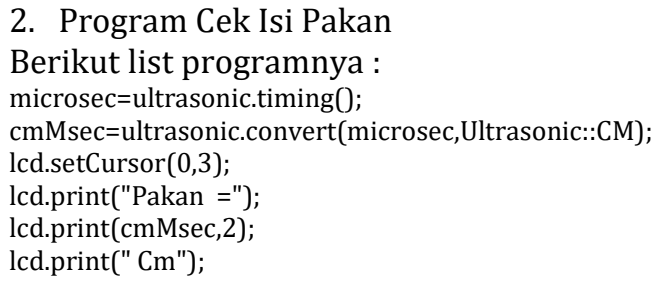

Pada kode program cmMsec=ultrasonic.convert berfungsi untuk membaca jarak pakan (pelet) dengan sensor ultrasonik dalam satuan $\mathrm{cm}$ sebagai acuan ketersediaan pakan dalam tangki pakan.

\section{Program Cek Pakan}

Berikut list programnya :

scale.set_scale(calibration_factor); //Adjust to this calibration factor units=scale.get units $(0,10$;

lcd.setCursor $(0,2)$;

lcd.print("Pakan=");

lcd.print(units);

lcd.print(" gram");

Pada kode program units berfungsi untuk menampilkan berapa unit atau berat banyak pakan (pelet) dalam satuan gram yang terbaca oleh sensor yang nantinya akan ditumpahkan menuju pelontar.

\section{Program Cek Suhu Air}

Berikut list programnya :

Celcius=sensors.getTempCByIndex(0);

lcd.setCursor $(0,2)$;

lcd.print("Temp =");

lcd.print(Celcius); lcd.print(" 'C");

Pada kode program Temp berfungsi untuk menampilkan suhu atau temperatur air dalam satuan celcius.
5. Program Motor Servo

a) Program untuk Motor Servo 1

Berikut list programnya :

for $($ pos $=15$; pos $<=50$; pos $+=1)\{$ myservo1.write(pos);

delay(15);

for $($ pos $=50$; pos $>=15$; pos- $=1$ ) \{

myservo1.write(pos);

delay(15);

b) Program untuk Motor Servo 2

Berikut list programnya :

for $\left(\operatorname{pos}=15\right.$; $\operatorname{pos}_{<}=180$; $\left.\operatorname{pos}^{+}=1\right)\{$

myservo2.write(pos);

delay(30);

for $(\operatorname{pos}=15 ; \operatorname{pos}<=180 ; \operatorname{pos}+=1)\{$

myservo2.write(pos);

delay(30);

Pada kode program pos berfungsi untuk menentukan posisi derajat kemiringan servo. Pada motor servo 1 menentukan posisi derajat kemiringan bertujuan agar pakan jatuh dari tangki pakan menuju wadah penampung. Kode program delay(15) berguna untuk menginstruksikan program akan berjalan selama 0,0015 detik.

Pada motor servo 2 menentukan posisi derajat kemiringan bertujuan agar pakan yang telah ditimbang pada sensor loadcell dapat tumpah menuju pelontar. Pada motor servo 2 untuk menginstruksikan program akan berjalan selama 0,003 detik.

6. Program Motor DC

a) Motor Aktif

Berikut list programnya :

analogWrite(M1,100);

digitalWrite(M2,LOW);

delay(5000);

Pada kode program analogWrite $(M 1,100)$ dan digitalWrite(M2,LOW) menyatakan motor dalam kondisi high dan low. Nilai variabel 100 pada kode analogWrite $(M 1,100)$ merupakan kode untuk mengatur kecepatan pada motor DC atau nilai PWM (pulse width modulation). Jika ingin menambah kecepatan motor maka nilai PWM juga dinaikkan sedangkan jika ingin mengurangi kecepatan pada motor DC maka nilai PWM juga diturunkan.

\section{b) Motor Stop}

Berikut list programnya :

digitalWrite(M1,LOW);

digitalWrite(M2,LOW);

delay(100);

Pada kode program analogWrite $(M 1,100)$ dan digitalWrite $(\mathrm{M} 2, \mathrm{LOW})$ motor dalam kondisi low dan low yang menyatakan bahwa motor tidak memiliki tegangan sehingga motor berhenti. 
7. Program Buzzer dengan Pengkondisian Sensor Ultrasonik

Berikut list programnya :

digitalWrite(buz,HIGH);

else if (stat $==1$ )

digitalWrite(buz,digitalRead(buz) ^ 1);

if $(\mathrm{cmMsec}>=21)\{$

stat $=1$;

if $($ stat $==0)\{$

Pada kode program if ( $\mathrm{cmMsec}>=21)\{$ stat=1 berfungsi untuk mengaktifkan buzzer jika jarak pakan (pelet) lebih dari $21 \mathrm{~cm}$

8. Program Pengaturan Pemberian Pakan Berdasarkan Waktu dan Suhu Air.

Berikut list programnya :

if $($ MyDateAndTime.Hour $==8$ and MyDateAndTime.Minute $==0$ and

MyDateAndTime.Second $<=5)\{$

lcd.clear0;

lcd.setCursor $(0,0)$;

lcd.print("Proses Pakan Pagi ");

lcd.setCursor(0,1);

lcd.print("Temp Air = ");

lcd.print(Celcius);

lcd.print(" 'C");

if (Celcius $>=4$ and Celcius $<=24)\{$

sett $=30 ;\}$

else if (Celcius $>=24$ and Celcius $<=32$ ) \{

sett $=41 ;\}$

else if (Celcius $>=32$ and Celcius $<=37$ ) \{

sett $=50 ;\}$

for $(\operatorname{pos}=15 ; \operatorname{pos}<=50$; pos $+=1)\{$

Program diatas merupakan potongan pengaturan waktu pemberian pakan, jumlah pakan dengan suhu air. Dimana jumlah pakan yang akan ditumpahkan akan disesuaikan dengan suhu yang terbaca oleh sensor suhu.

\section{Pengujian Alat Secara Keseluruhan}

Adapun tujuan pengujian ini untuk melihat sejauh mana hasil dari kerja alat system otomatisasi pemberian pakan, sehingga didapat hasil dan perbandingan dari apa yang direncanakan sebelumnya. Pada tahap ini, alat akan dioperasikan secara normal dengan menghubungkan ke kontak listrik. Pengujian alat secara keselutruhan dapat dilihat pada tabel 8 .
Tabel 8. Pengujian Alat Keseluruhan

\begin{tabular}{|c|c|c|c|c|c|}
\hline \multirow{2}{*}{$\begin{array}{c}\text { Hari dan } \\
\text { Tanggal }\end{array}$} & \multirow[t]{2}{*}{ Waktu } & \multicolumn{2}{|c|}{ Kondisi Servo } & \multirow{2}{*}{$\begin{array}{l}\text { Suhu } \\
\text { (C) }\end{array}$} & \multirow{2}{*}{$\begin{array}{c}\text { Banyak } \\
\text { Pakan } \\
\text { (gram) }\end{array}$} \\
\hline & & Aktif & $\begin{array}{l}\text { Tidak } \\
\text { Aktif }\end{array}$ & & \\
\hline \multirow{5}{*}{$\begin{array}{c}\text { Kamis, } 15 \\
\text { Oktober } \\
2020\end{array}$} & 08.00 & $\checkmark$ & & 24,30 & 41,13 \\
\hline & 13.00 & & $\checkmark$ & 27,15 & 0 \\
\hline & 13.30 & $\checkmark$ & & 27,55 & 41,20 \\
\hline & 16.00 & & $\checkmark$ & 26,25 & 0 \\
\hline & 19.00 & $\checkmark$ & & 26,10 & 42,50 \\
\hline \multirow{6}{*}{$\begin{array}{c}\text { Selasa, } 19 \\
\text { Oktober } \\
2020\end{array}$} & 08.00 & $\checkmark$ & & 26,25 & 40,15 \\
\hline & 10.00 & & $\checkmark$ & 26,20 & 0 \\
\hline & 13.12 & & $\checkmark$ & 28,80 & 0 \\
\hline & 13.30 & $\checkmark$ & & 28,94 & 41,46 \\
\hline & 17.00 & & $\checkmark$ & 27,62 & 0 \\
\hline & 19.00 & $\checkmark$ & & 26,10 & 42,80 \\
\hline \multirow{5}{*}{$\begin{array}{c}\text { Rabu, } 04 \\
\text { November } \\
2020\end{array}$} & 10.30 & & $\checkmark$ & 27,35 & 0 \\
\hline & 13.30 & $\checkmark$ & & 27,30 & 41 \\
\hline & 15.00 & & $\checkmark$ & 27,10 & 0 \\
\hline & 17.15 & & $\checkmark$ & 26,40 & 0 \\
\hline & 19.00 & $\checkmark$ & & 26,10 & 41,13 \\
\hline \multirow{5}{*}{$\begin{array}{c}\text { Kamis, } 05 \\
\text { November } \\
2020\end{array}$} & 07.00 & & $\checkmark$ & 24.5 & 0 \\
\hline & 08.00 & $\checkmark$ & & 24,25 & 41,20 \\
\hline & 10.30 & & $\checkmark$ & 26,20 & 0 \\
\hline & 12.30 & & $\checkmark$ & 26,98 & 0 \\
\hline & 13.30 & $\checkmark$ & & 27,20 & 41,25 \\
\hline
\end{tabular}

\section{KESIMPULAN}

Berdasarkan hasil pengujian terhadap rancang bangun alat pemeberi pakan ikan otomatis berbasis suhu air pada kolam ikan menggunakan arduino, maka diperoleh kesimpulan sebagai berikut :

1. Alat ini mampu melakukan sistem otomatisasi pada pemberian pakan ikan secara keseluruhan yang meliputi pemberian pakan ikan berdasarkan suhu air.

2. Setiap komponen pada alat ini dapat bekerja dengan baik sesuai fungsi masing-masing.

\section{REFERENSI}

[1] M. S. Daulah, D. Syauqy, and R. Primananda, "Implementasi Protokol MQTT Pada Monitoring Suhu Dan Ketersediaan Pakan Ikan Pada Akuarium," J. Pengemb. Teknol. Inf. dan Ilmu Komput. e-ISSN, vol. 2548, p. 964X, 2018.

[2] P. C. Sihombing, "Pengaruh Perbedaan Suhu Air Terhadap dan Kelangsungan Benih Hidup Ikan Nila (Oreochromis Niloticus," Repos. Institusi USU, 2018.

[3] F. K. Alblitary, "Rancang Bangun Alat Pemberi Pakan Ikan Otomatis Pada Kolam Ikan Gurami Berbasis Arduino." Institut Teknologi Sepuluh Nopember, 2017.

[4] D. M. Kelabora, "Pengaruh suhu terhadap kelangsungan hidup dan pertumbuhan larva ikan mas (Cyprinus carpio)," Berk. Perikan. Terubuk, vol. 38, no. 1, 2010.

[5] R. Suharmon, "Perancangan alat pemberi makan ikan otomatis dan pemantau keadaan akuarium berbasis mikrokontroler ATmega8535," 2014. 
[6] D. T. Gandara and S. Nuryadi, "PEMBERI PAKAN IKAN OTOMATIS DENGAN PENGONTROLAN SUHU DAN KEJERNIHAN AIR Berbasis Arduino." University of Technology Yogyakarta, 2018.

[7] Afdhal Rafif, Perancangan Kontrol Ketinggian Air dan Pemberian Pakan Ikan pada Sistem Mina Padi Menggunakan Mikrokontroler Arduino Mega 2560. Padang, 2019.

[8] S. Raharjo, E. Kurniawan, and E. D. Nurcahya, "SISTEM OTOMATISASI FOTOSINTESIS BUATAN PADA AQUASCAPE BERBASIS ARDUINO," KOMPUTEK, vol. 2, no. 1, pp. 39-49, 2018.

[9] A. S. A. Putri, A. Rasyid, and A. W. Purwandi, "Smart cat home dengan sistem kontrol yang menggunakan aplikasi telegram," J. Jartel J. Jar. Telekomun., vol. 8, no. 1, p. 168, 2019.

[10] R. A. W. Putra, E. Firmansyah, and F. D. Wijaya, "Metode six step comutation pada perancangan rangkian kendali sensored motor brushless direct current," J. Penelit. Tek. Elektro dan Teknol. Inf., vol. 1 , no. $1,2014$.

\section{Biodata Penulis}

Sandya Pratisca, lahir di Batam, 19 Desember 1997. Menyelesaikan studi D1V Teknik Elektro Industri pada Jurusan Teknik Elektro Fakultas Teknik Universitas Negeri Padang.

Juli Sardi, S.Pd, M.T, lahir di Dhamasraya, 18 Juli 1987. Menelesaikan studi S1 di Universitas Negeri Padang tahun 2010. Pendidikan S2 di Institut Teknologi Sepuluh Nopember tahun 2013. Saat ini terdaftar sebagai dosen pengajar pada Jurusan Teknik Elektro Universitas Negeri Padang. 